\title{
SERUM GONADOTROPHIN LEVELS IN PRO-OESTROUS RATS IN RELATION TO THE RESUMPTION OF MEIOSIS BY THE OOCYTES
}

\author{
D. AYALON, A. TSAFRIRI, H. R. LINDNER, T. CORDOVA \\ AND A. HARELL
}

Department of Biodynamics, The Weizmann Institute of Science, Rehovot, Israel

\author{
(Received 17th August 1971, accepted 2nd December 1971)
}

\begin{abstract}
Summary. Serum levels of $\mathrm{LH}$, FSH and prolactin were determined in pro-oestrous rats by radioimmunoassay, and the time of commitment of oocytes to undergo maturation was defined by explanting follicles at hourly intervals into a hormone-free medium. All three pituitary hormones showed a rise during the afternoon of pro-oestrus. The prolactin level was still elevated on the morning of oestrus, and serum FSH showed a secondary rise at that time. Administration of pentobarbitone-sodium at 14.00 hours abolished the afternoon rise in the levels of LH and FSH, but not of prolactin, and prevented the induction of oocyte maturation.

The percentage of oocytes that completed the first meiotic division when explanted within intact follicles increased during the afternoon of pro-oestrus from $<5 \%$ at 14.30 to $80 \%$ at 17.30 hours. This maturation commitment preceded the dissolution in vivo of the germinal vesicle by about $1 \frac{1}{2} \mathrm{hr}$. Its attainment closely followed the rising curve of serum LH concentration, indicating that only brief exposure of the follicle to LH is required to initiate ovum maturation.
\end{abstract}

\section{INTRODUCTION}

On the day of pro-oestrus, the rat ovary usually presents four to seven enlarged follicles (about $1 \mathrm{~mm}$ in diameter) protruding from the ovarian surface. When these are isolated by microdissection and cultured intact, it is possible to distinguish two stages of development: (1) follicles in which the oocytes fail to mature in hormone-free media, but do so on addition of $\mathrm{LH}$; (2) follicles which give rise in culture to secondary oocytes without any requirement for added hormones. In the following study, the latter follicles are referred to as 'committed,' and it is assumed that they have received in vivo an adequate hormonal stimulus for the resumption of meiosis by the oocyte. All follicles collected on the morning of pro-oestrus were found to be of the first category (Tsafriri, Lindner, Zor \& Lamprecht, 1972). However, when follicles were explanted at progressively later times during the afternoon, an increasing proportion proved to be of the 'committed' type, even though it was usually impossible, at the time 
of collection, to discern any morphological signs of imminent ovum maturation, such as the dissolution of the germinal vesicle.

One purpose of this study was to examine the temporal relationship between the preovulatory rise in plasma gonadotrophin levels and the acquisition of maturation commitment by the oocytes. We also wished to examine how pentobarbitone administration, long known to block ovulation when carried out during a 'critical period' (Everett, 1961), affects plasma gonadotrophin and prolactin levels as well as the behaviour of explanted follicles.

\section{MATERIALS AND METHODS}

\section{Animals and treatments}

Three-month-old female rats of the Biodynamics colony, derived from the Wistar strain and weighing about $200 \mathrm{~g}$, were used. The animals selected had shown at least two normal 4-day cycles, as determined by daily vaginal smears, immediately before the start of the experiment. The animals were housed in airconditioned quarters illuminated between 05.00 and 19.00 hours, and were separated from males. They were offered Purina Laboratory Chow and water without restriction. One group of the animals received pentobarbitone sodium (Nembutal, Abbot, $30 \mathrm{mg} / \mathrm{kg}$ body weight) by intraperitoneal injection, between 13.50 and 14.10 hours on the day of pro-oestrus.

\section{Blood collections}

On the day of pro-oestrus, at the times indicated, and on the morning of oestrus (09.00 hours), four rats from the control group and four from the Nembutal-treated group were bled by cardiac puncture under light ether anaesthesia and killed for collection of ova. The blood was allowed to clot for $2 \mathrm{hr}$ at room temperature and placed in a refrigerator at $4^{\circ} \mathrm{C}$ for $24 \mathrm{hr}$. The serum was collected by centrifugation at $2000 \mathrm{rev} / \mathrm{min}$ for $10 \mathrm{~min}$ at $4^{\circ} \mathrm{C}$ and stored at $-20^{\circ} \mathrm{C}$ until used for the hormone assays. Each sample served for the assay of $\mathbf{L H}, \mathrm{FSH}$ and prolactin.

\section{Examination of fresh ova}

Oocytes from large follicles of the rats bled for hormone assays on the day of pro-oestrus were collected and examined by interference microscopy for presence or absence of a germinal vesicle and nucleolus. In rats bled on the morning of oestrus, the occurrence of ovulation was verified by recovery of tubal ova.

\section{Culture of follicle-enclosed ova}

Intact follicles were isolated by microdissection from the ovaries of prooestrous rats treated with Nembutal and from untreated rats at the times specified, and these were cultured as described by Tsafriri, Lindner, Zor \& Lamprecht (1972). At the end of 12 to $18 \mathrm{hr}$ incubation, the oocytes were examined by interference microscopy. If the germinal vesicle had disappeared, completion of the first meiotic division was confirmed by scrutiny of chromosome preparations made according to the method of Tarkowski (1966). 
Radioimmunoassay of pituitary hormones in serum

All hormone assays were carried out in duplicate.

Luteinizing hormone was assayed by the method of Monroe, Parlow \& Midgley (1968). For radioiodination, Purified Rat LH (NIAMD-Rat LH-I-1) was used which was approximately equipotent with NIH-LH-sl in the ovarian ascorbic acid depletion (OAAD) assay, and essentially devoid of FSH contamination (potency in the HCG augmentation test $<0.04 \times$ NIH-FSH-sl). The antiserum used was NIAMD-Anti-Rat LH Serum-1, and the reference preparation for calibrating the standard curves was NIAMD-Rat LH-RP-1, which has a stated biological potency 0.03 times that of NIH-LH-s1 in the OAAD assay. The results were expressed in terms of NIH-LH-sl.

The standard deviation of the difference between the results of duplicate determinations (Snedecor, 1952), taken as a measure of the precision of the assay, was $0.90 \mathrm{ng}$ (coefficient of variation $=11.3 \%$ ) for samples of low LH content ( 5 to $15 \mathrm{ng} / \mathrm{ml} ; 150$ pairs), and $3.9 \mathrm{ng}$ (coefficient of variation $=12.1 \%$ ) for samples of high LH content ( 16 to $60 \mathrm{ng} / \mathrm{ml}$; twenty-one pairs).

Follicle-stimulating hormone was assayed by a method kindly made available by Dr A. F. Parlow and since published by Daane \& Parlow (1971), using NIAMD-Rat FSH-I-1 for radioiodination. This preparation has a stated potency which is a hundred times that of NIH-FSH-sl in the HCG augmentation test and contains LH activity (OAAD assay) equivalent to $<0.002$ times its weight of NIH-LH-sl. The antiserum used was NIAMD-Anti-Rat FsH Serum-1, and the reference preparation was NIAMD-Rat FsH-RP-1, with a potency $2 \cdot 1$ times higher than NIH-FSH-Sl in the HCG augmentation test. The results were expressed in terms of NIH-FSH-s 1 . The coefficient of variation was $11.4 \%$ for the concentration range 0.6 to $3 \mu \mathrm{g} / \mathrm{ml}$ (170 pairs).

Prolactin was assayed according to Niswender, Chen, Midgley, Meites \& Ellis (1969), using NIAMD-Rat-Prolactin-I-1 for radioiodination (estimated biological potency in the crop sac assay, $30 \mathrm{i} . \mathrm{u} . / \mathrm{mg}$ ). The antiserum used was NIAMD-Anti-Rat Serum-1, and the reference preparation used for establishing the standard curves was NIAMD-Rat Prolactin RP-1. The results were expressed in terms of NIAMD-Rat Prolactin-RP-1.

The coefficient of variation was $20 \%$ for the lower prolactin concentration range (25 to $150 \mathrm{ng} / \mathrm{ml} ; 180$ pairs) and $15 \%$ for the range 151 to $900 \mathrm{ng} / \mathrm{ml}$ (130 pairs).

\section{RESULTS}

Serum gonadotrophin and prolactin levels during pro-oestrus in untreated and pentobarbitone-treated rats

Serum LH levels were uniformly low, fluctuating about a mean of $9 \mathrm{ng} / \mathrm{ml}$, throughout the morning of the day of pro-oestrus, and began to rise in the early afternoon (about 15.00 hours) to reach a peak (mean $59 \mathrm{ng} / \mathrm{ml}$ ) by about 17.00 hours (Text-fig. 1). The LH levels remained elevated until 18.30 hours, and returned to basal values by 21.00 hours. It should be stressed that each point in Text-fig. 1 represents the mean value for a different group of animals; the preovulatory LH peak may well have been narrower if sequential samples from individual animals could have been obtained. 


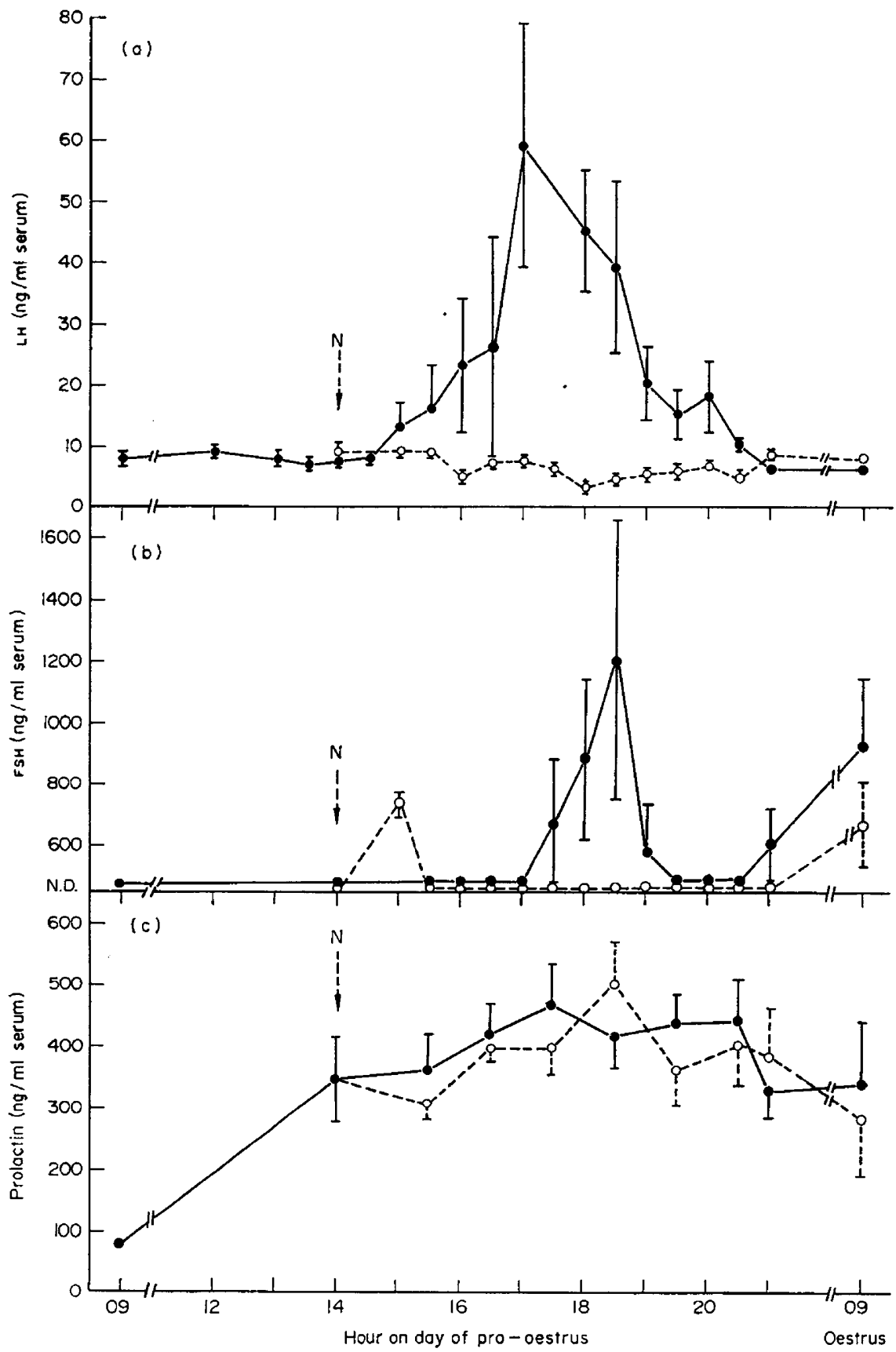

TEXT-FIG. 1. Serum levels of (a) LH, (b) FSH and (c) prolactin in normal and Nembutaltreated rats. The hormones were determined by radioimmunoassay as described in the 'Materials and Methods' section. Serum LH was expressed in terms of NHH-LH-sl, FSH in terms of NIH-FSH-s1, and prolactin in terms of NIAMD-Rat Prolactin RP-1. $\bullet$, Control groups; $O$, pentobarbital-treated groups. $N$, injection of Nembutal. Vertical lines indicate \pm S.E. 
The administration of Nembutal at 14.00 hours on the day of pro-oestrus completely abolished the afternoon rise of serum LH.

Serum FSH levels in the same animals were generally below the level of sensitivity of the assay used (i.e. $<60 \mathrm{ng}$ in samples of $0 \cdot 1 \mathrm{ml}$ serum) throughout the morning and early afternoon of pro-oestrus, and became measurable only in the late afternoon, reaching a peak $(1 \cdot 2 \mu \mathrm{g} / \mathrm{ml})$ at 18.30 hours (Text-fig. $1 \mathrm{~b}$ ). The precise time of onset of this rise could not be ascertained because of the

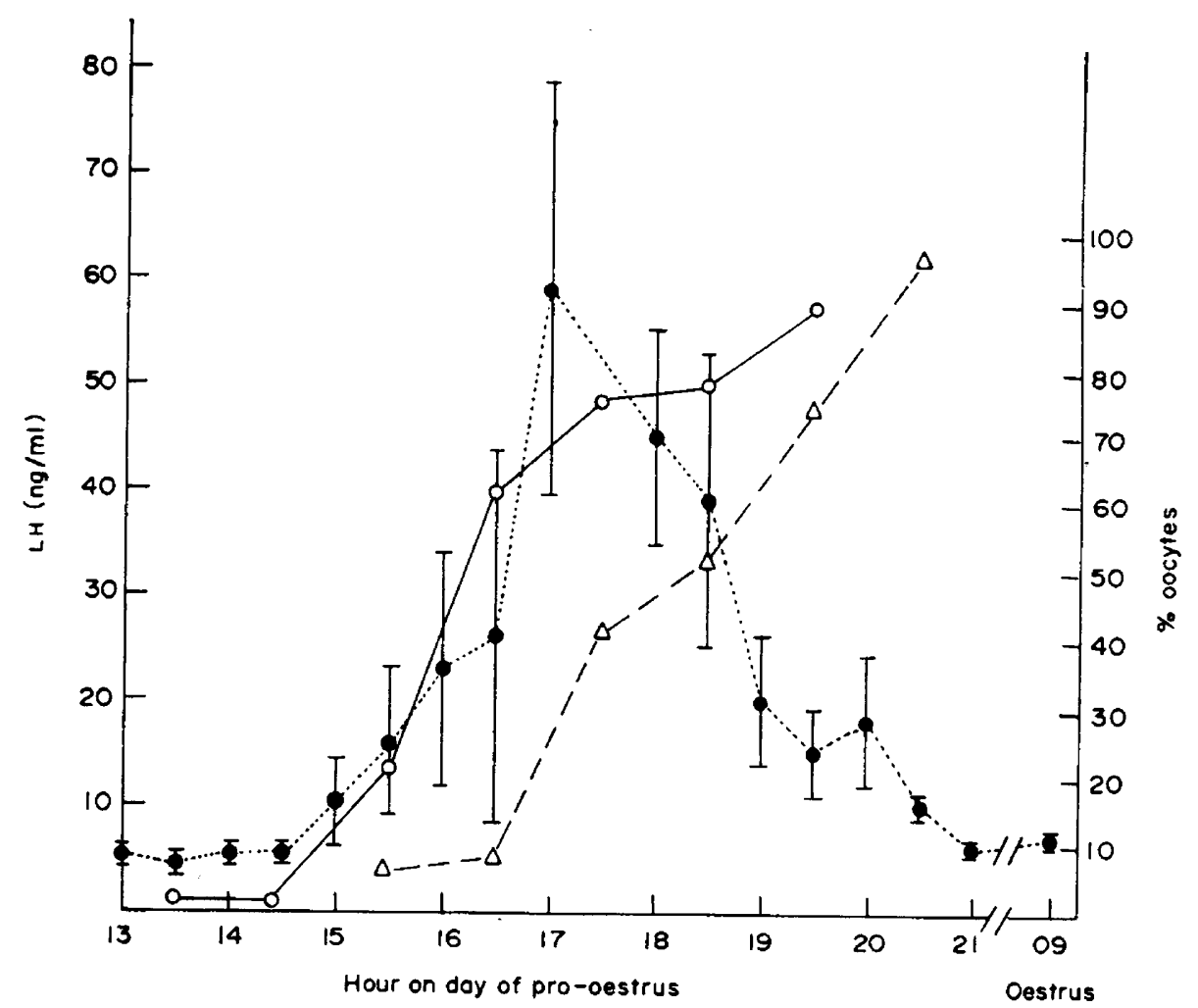

TExT-FIG. 2. Temporal relation between plasma LH-level, maturation commitment and in-vivo resumption of meiosis. Plasma LH was determined by radioimmunoassay as described in the 'Materials and Methods' section. Data on time of disappearance of the germinal vesicle in vivo were taken from Tsafriri \& Kraicer (1972), who used the same animal colony, and were confirmed in the present study. $Q$, NIH-LH-sl equivalent (ng/ml \pm S.E.); $O$, maturation commitment (oocytes resuming meiosis when follicle explanted to hormone-free medium); $\Delta$, resumption of meiosis in vivo (disappearance of germinal vesicle and nucleolus).

inability of the assay to determine values near the basal FsH level, and may well have occurred earlier than is apparent from Text-fig. 1 (b). The FsH level was again elevated on the morning of the day of oestrus. The afternoon rise in serum FSH concentration was obliterated by the Nembutal treatment, although there was a transient increase $1 \mathrm{hr}$ after the injection.

Serum prolactin levels were low in the early morning $(80 \mathrm{ng} / \mathrm{ml}$ at 09.00 hours), but elevated throughout the afternoon of pro-oestrus (group means 360 
to $470 \mathrm{ng} / \mathrm{ml})$ and were still high $(340 \mathrm{ng} / \mathrm{ml})$ on the morning of the day of oestrus (Text-fig. 1c). Nembutal treatment had no significant effect on prolactin levels on the day of pro-oestrus.

Acquisition of oval maturation commitment in relation to serum gonadotrophin levels

The percentage of oocytes that resumed meiosis when explanted within the intact follicle on the day of pro-oestrus into a hormone-free medium remained below $5 \%$ until 14.30 hours, but rose during the afternoon to $20 \%$ at 15.30 hours and $80 \%$ at 17.30 hours, at the same rate as the rise in serum LH level (Table 1 and Text-fig. 2). On average, this maturation commitment preceded the disappearance in vivo of the germinal vesicle and nucleolus (cf. Tsafriri \& Kraicer, 1972) by about $1 \frac{1}{2}$ hr (Text-fig. 2). Treatment of the rats with Nembutal at 14.00 hours prevented follicle-enclosed oocytes from attaining the capacity to mature in hormone-free media when explanted in the late afternoon (Table 1).

\section{TABLE 1}

EFFEGT OF TIME OF EXPLANTATION AND OF PENTOBARBITONE ON MATURATION OF FOLLICLE-ENGLOSED OOCYTES CULTURED IN HORMONE-FREE MEDIUM

\begin{tabular}{c|c|c|c|c|c|c}
\hline $\begin{array}{c}\text { Nembutal } \\
(30 \mathrm{mg} / \mathrm{kg}) \\
\text { at } 14.00 \\
\text { hours }\end{array}$ & $\begin{array}{c}\text { Time of } \\
\text { explantation } \\
\text { (hours) }\end{array}$ & $\begin{array}{c}\text { No. of } \\
\text { follicles }\end{array}$ & \multicolumn{4}{|c}{ Oocytes recovered } \\
\hline- & 08.30 to 12.30 & 110 & 75 & 95 & 4 & 1 \\
- & 17.00 to 20.00 & 376 & 277 & 12 & 79 & 9 \\
+ & 17.00 to 20.00 & 82 & 54 & 88 & 8 & 4 \\
\hline
\end{tabular}

\section{DISGUSSION}

The culture of intact follicles explanted during the morning of pro-oestrus provides a test system, isolated from the animal's own endocrine glands, for assessing the ability of various hormonal preparations to induce maturation of the oocyte. Using this system, it was shown that exogenous LH and FSH, but not prolactin, could bring about completion of the first meiotic division (Tsafriri, Lindner, Zor \& Lamprecht, 1972). The culture of follicles explanted at progressively later times during the afternoon of pro-oestrus helped to define the precise time at which the oocyte or follicle has received an adequate dose of endogenous ovulatory hormone(s) to initiate, irreversibly, the resumption of the meiotic process.

All three pituitary hormones assayed in this study showed a rise during the afternoon of pro-oestrus, in essential agreement with reports by Goldman, Kamberi, Siiteri \& Porter (1969), Gay, Midgley \& Niswender (1970), Wuttke \& Meites (1970), and Daane \& Parlow (1971). Administration of Nembutal at 14.00 hours on the day of pro-oestrus prevented the afternoon rise of serum LH and FSH levels, as well as the induction of oocyte maturation in vivo, as revealed by the behaviour of follicle-enclosed oocytes explanted into hormone-free 
media. Nembutal was also shown by Wuttke $\&$ Meites (1970) to suppress the preovulatory LH rise, and Daane \& Parlow (1971) obtained partial inhibition of the FsH rise. However, in contrast to the findings of Wuttke \& Meites (1970), Nembutal injection did not affect serum prolactin levels, confirming that prolactin on its own is unable to elicit ovum maturation.

Purified Fsh preparations have been reported to induce ovulation (Harrington, Bex, Elton \& Roach, 1970) and ovum maturation (Tsafriri, Lindner, Zor \& Lamprecht, 1972). Nevertheless, an inherent ability of FsH to bring about these effects, independent of either the participation of the animal's own pituitary or of the presence of contaminating LH-like activity in the FSH preparation used, had not been established beyond doubt. The present results do not help resolve this issue. Although a rise in FsH level could be demonstrated only at a time when the LH level had already reached its peak and most oocytes were committed to resume meiosis, this delay may have been more apparent than real, since it could have resulted from the lower sensitivity of the FSH assay.

The increase in the percentage of committed oocytes during the course of the afternoon of pro-oestrus practically coincided with the rising curve of serum LH concentration (Text-fig. 2), suggesting that only brief contact of the follicles with $\mathrm{LH}$ is required to trigger the resumption of meiosis. Thereafter, LH is either not needed for the process of maturation, or else it is effectively retained by cellular receptors within the follicle.

The maturation commitment in vivo is attained, on the average, about $1 \frac{1}{2} \mathrm{hr}$ before the loss of the germinal vesicle and nucleolus of the oocyte, as determined by Tsafriri \& Kraicer (1972) and confirmed in the present study (Textfig. 2). Obviously, it would be of great interest to study in greater detail the biochemical events associated with the initial interaction of LH with the follicle during this brief period of latency.

\section{ACKNOWLEDGMENTS}

We are indebted to Dr A. F. Parlow of the N.I.A.M.D. Rat Pituitary Hormone Distribution Program for the rat antisera and hormone preparations used, and for helpful instructions for their use. We are also grateful to Mrs A. Tsafriri and Miss M. Feuerstein for skilful technical assistance, to Mr S. Yosef for devoted animal care, and to Professor P. F. Kraicer for the interest taken in this study. The contribution of one of the authors (A.T.) constitutes part of the requirements for the Ph.D. degree of the Graduate School of the Weizmann Institute of Science. The work was generously supported by the Population Council, New York, and by the Ford Foundation.

\section{REFERENCES}

Daane, T. A. \& Parlow, A. F. (1971) Periovulatory patterns of rat serum follicle stimulating hormone and luteinizing hormone during the normal estrous cycle: effects of pentobarbital. Endocrinology, 88, 653.

EVERETT, J. W. (1961) The mammalian female reproductive cycle and its controlling mechanisms. In: Sex and Internal Secretions, 3rd edn, Vol. 1, p. 491. Ed. W. G. Young. Williams \& Wilkins, Baltimore.

Gay, V. L., Midgley, A. R., JR \& Niswender, G. D. (1970) Patterns of gonadotrophin secretion associated with ovulation. Fedn Proc. Fedn Am. Socs exp. Biol. 29, 1880. 
Goldman, B. D., Kamberi, I. A., Sirteri, P. K. \& Porter, J. C. (1969) Temporal relationship of progestin secretion, LH release and ovulation in rats. Endocrinology, 85, 1137.

Harrington, F. E., Bex, F. J., Elton, R. L. \& Roach, J. B. (1970) The ovulatory effects of follicle stimulating hormone treated with chymotrypsin in chlorpromazine blocked rats. Acta endocr., Copenh. 65, 222.

Monroe, S. E., PArlow, A. F. \& Midgley, A. R., JR (1968) Radioimmunoassay for rat luteinizing hormone. Endocrinology, 83, 1004.

Niswender, G. D., Chen, C. L., Midgley, A. R., Jr, Mertes, J. \& Ellis, S. (1969) Radioimmunoassay for rat prolactin. Proc. Soc. exp. Biol. Med. 130, 793.

SNedecor, G. W. (1952) Query no. 92. Biometrics, 8, 85.

TARKowsKI, A. K. (1966) An air-drying method for chromosome preparations from mouse eggs. Cytogenetics, 5, 394.

TsAFrirI, A. \& KRAICER, P. F. (1972) The time sequence of ovum maturation in the rat. F. Reprod. Fert. $29,387$.

Tsafriri, A., Lindner, H. R., Zor, U. \& LAMpreght, S. A. (1972) In-vitro induction of meiotic division in follicle-enclosed rat oocytes by $\mathrm{LH}$, cyclic AMP and prostaglandin $\mathrm{E}_{\mathbf{2}}$. F. Reprod. Fert. 31, 39.

Wuttke, W. \& MeItes, J. (1970) Effects of ether and pentobarbital on serum prolactin and LH levels in proestrous rats. Proc. Soc. exp. Biol. Med. 135, 648. 